Sains Malaysiana 50(8)(2021): 2355-2365

http://doi.org/10.17576/jsm-2021-5008-18

\title{
Expired Platelet Concentrate as a Source of Human Platelet Lysate for Xenogeneic- Free Culture of Human Dermal Fibroblasts
}

(Platelet Pekat Tamat Tempoh sebagai Sumber Platelet Lisat Manusia untuk Pengkulturan Sel Fibroblas Kulit

Manusia secara Bebas Xenogenik)

Muhammad Najib Fathi bin Hassan, Zheng Yie Yap, Yee Loong Tang, Min Hwei Ng \& Jia Xian LAw*

\begin{abstract}
Dermal fibroblasts have been used clinically to promote wound healing and to reduce wrinkles. Most of the time, fetal bovine serum (FBS) is used for the expansion of fibroblasts. In addition, chemically defined medium can also be used for fibroblast expansion. Nonetheless, both FBS and chemically defined medium are not ideal to culture cells that will be used clinically as FBS has the risk of pathogen transmission and induction of xenogeneic immune response whilst chemically defined medium is extremely expensive. In this study, we examine the potential of using human platelet lysate $(\mathrm{hPL})$ prepared from expired platelet concentrates to culture human dermal fibroblasts. For the experiments, fibroblasts were cultured with 5 and $10 \%$ hPL, with 10\% FBS as the control group to compare the cell morphology, viability, growth rate, extracellular matrix gene expression and wound healing. Results showed that fibroblasts cultured with hPL were more elongated and smaller in size. The cell viability was higher than $90 \%$ for all groups. Expansion with $10 \%$ hPL significantly shorten the population doubling time compared to the 5\% hPL and 10\% FBS groups. However, fibroblasts cultured with hPL have lower expression of type I collagen, type III collagen and fibronection as well as slower wound closure. In summary, hPL has the potential to be used as a serum substitute for FBS to expand fibroblasts as it significantly increases the cell proliferation. However, further studies are required to determine if the changes in the ECM gene expression and migration of the hPL-expanded fibroblasts will affect the efficacy of the cells in promoting in vivo wound healing.
\end{abstract}

Keywords: Cell culture; fibroblast; human platelet lysate; platelet concentrate; skin

ABSTRAK

Sel fibroblas kulit telah digunakan secara klinikal untuk merangsang penyembuhan luka dan mengurangkan kedut. Kebiasaanya, serum fetus lembu (FBS) paling kerap digunakan untuk pengkulturan sel fibroblas. Pada masa yang sama, media ditakrifkan secara kimia juga boleh digunakan untuk pengkulturan sel fibroblas. Namun demikian, kedua-dua FBS and media ditakrifkan secara kimia adalah tidak ideal untuk penghasilan besar-besaran sel fibroblas untuk kegunaan klinikal kerana FBS mempunyai risiko penjalaran patogen haiwan dan penolakan oleh sistem imun pesakit manakala media tanpa serum adalah sangat mahal. Dalam kajian ini, potensi platelet lisat manusia (hPL) yang disediakan daripada platelet pekat tamat tempoh untuk pengkulturan sel fibroblas telah dikaji. Untuk tujuan uji kaji, sel fibroblas dikultur dengan 5\% hPL dan 10\% hPL dengan 10\% FBS sebagai kumpulan kawalan untuk menilai perbezaan morfologi sel, kebolehhidupan sel, kadar pertumbuhan sel, ekspresi gen-gen matriks extrasel dan penyembuhan luka. Hasil kajian mendapati sel fibroblas dikultur dengan hPL adalah lebih gelendong dan kecil berbanding dengan sel yang dikultur dengan FBS. Kebolehhidupan sel melebihi 90\% untuk semua kumpulan kajian. Kadar pertumbuhan sel adalah lebih tinggi untuk kumpulan 10\% hPL berbanding dengan kumpulan yang lain. Namun demikian, sel yang dikultur dengan hPL mempunyai ekspresi kolagen kumpulan I, kolagen kumpulan III dan fibronectin yang lebih rendah serta penyembuhan luka yang lebih lambat. Secara kesimpulan, hPL berpotensi menggantikan FBS untuk pengkulturan sel 
fibroblas kerana ia merangsang proliferasi sel. Namun demikian, penyelidikan lanjutan perlu dijalankan untuk mengenal pasti sama ada perubahan dalam ekspresi gen ekstrasel and migrasi akan menjejaskan efikasi sel-sel tersebut dalam merangsang penyembuhan luka secara in vivo.

Kata kunci: Fibroblas; kulit; pengkulturan sel; platelet lisat manusia; platelet pekat

\section{INTRODUCTION}

Fetal bovine serum (FBS) is commonly used in in vitro cell expansion as it is rich in hormones, growth promoting factors and attachment factors that support cell survival, attachment, and proliferation (Yao \& Asayama 2017). However, production of FBS is associated with ethical and animal welfare issues (Jochems et al. 2002). Furthermore, the use of FBS as cell culture supplement is discouraged by the regulatory authority to limit the risk of animal pathogen transmission and activation of xenogeneic immune response in the transplanted host (Astori et al. 2016). Currently, chemically defined medium and human-derived supplements such as human serum and human platelet lysate (hPL) are being explored as potential xenogeneic-free alternatives for FBS. Nonetheless, usage of chemically defined medium is extremely costly and supplementation with autologous serum is hampered by donor variability and availability.

HPL can be prepared from whole blood and platelet concentrate (Phetfong et al. 2017; Schallmoser \& Strunk 2009). Platelet concentrate is a blood product rich in platelet. In Malaysia, platelet concentrates in the blood bank only can be kept for 5 days at $20-24^{\circ} \mathrm{C}$ under constant agitation in accordance to the Ministry of Health guideline and will be discarded as biological waste if no transfusion is made (National Blood Centre 2016). Even though the platelet concentrates have expired, majority of the platelets and growth factors inside are still intact. Thus, expired platelet concentrates can be collected and processed into hPL for cell culture purposes.

Platelets are small colorless disk-shaped cell fragment that contribute to hemostasis and wound healing. Platelets are abundant in blood and are rich in growth factors and cytokines that are crucial in tissue repair and wound regeneration (Ruiz-Moneo et al. 2013). Platelets have been tested in many studies to treat a myriad of diseases. For example, we previously examined the potential of applying platelet rich plasma together with skin cells to promote wound regeneration (Law et al. 2017b). The possibility of using platelet lysate for cell culture also has been evaluated in previous studies (Fazzina et al. 2016; Hemeda et al. 2014).

HPL can be prepared from platelet concentrates through many different methods. Differences in the preparation methods resulted in variation in the efficacy of platelet granule disruption and subsequently the growth factor concentration. Thus, the quality of hPL varies from laboratory to laboratory. Repeated freezing-thawing is one of the simplest techniques to mechanically disrupt the platelet granules. Sonication is another physical method that has be used rupture the platelet granules. Physiological stimuli such as thrombin, collagen, adenosine diphosphate, thrombin receptor-activating peptide (TRAP), epinephrine, and calcium chloride can also be used to disrupt the platelet granules. Nonetheless, mechanical lysis is preferable as it is easier, less time consuming and more cost-effective (Astori et al. 2016).

HPL has been found to support proliferation of adipose- and bone marrow-derived mesenchymal stem cells (MSCs) without changing its surface marker expression profile, trilineage differentiation potential and immune regulatory properties (Gstraunthaler et al. 2015; Jonsdottir-Buch et al. 2013; Juhl et al. 2016). In addition, hPL can slow down MSC senescence and rejuvenate the senescent cells (Griffiths et al. 2013; Phetfong et al. 2017). However, a few studies reported contradict results whereby hPL is found to be inferior compared to FBS in promoting MSC proliferation and maintaining the cell functionality (Abdelrazik et al. 2011; Russell et al. 2015). Currently, no comprehensive report is available regarding the application of hPL to culture dermal fibroblasts. Only one study has reported that expansion with platelet-rich fibrin lysate (PRF-L) increased the proliferation, migration and collagen deposition of chronically UVA-irradiated human dermal fibroblasts (Wirohadidjojo et al. 2016). However, the authors used PRF-L at concentration 25 and $50 \%$ (v/v) which are much higher compared to the standard culture that uses $10 \%$ (v/v) serum. 
In this study, hPL is produced from expired platelet concentrates collected from the blood bank via repeated freezing-thawing cycles and subsequently tested for human dermal fibroblast expansion. Comparison between hPL and FBS as cell culture supplement is done by examining the cell morphology, proliferation, viability, migration, and extracellular matrix (ECM) gene expression.

\section{MATERIALS AND METHODS}

\section{PREPARATION OF PLATELET LYSATE}

The study was conducted with the approval from Universiti Kebangsaan Malaysia Research Ethics Committee (UKM PPI/111/8/JEP-2019-747). Expired platelet concentrates were collected from the blood bank at Universiti Kebangsaan Malaysia Medical Centre (UKMMC), Kuala Lumpur, Malaysia. Collected platelet concentrates were stored immediately at $-80{ }^{\circ} \mathrm{C}$. Each unit of platelet concentrate consist of $50 \pm 10 \mathrm{~mL}$ of plasma with total platelet count exceeding $60 \times 10^{9}$ platelet/ unit. The stored platelet concentrates (expired less than a year) was processed as previously described to prepare hPL (Budi Harto et al. 2019). Briefly, the frozen platelet concentrates were thawed in a $37{ }^{\circ} \mathrm{C}$ water bath and then freeze and thaw again to ensure complete release of platelet content. Then, the hPL was centrifugation at $2500 \mathrm{~g}$ for $20 \mathrm{~min}$ at $4{ }^{\circ} \mathrm{C}$ to remove cell debris. A total of $5 \mathrm{hPL}$ from 5 different donors were pooled and stored at $-20^{\circ} \mathrm{C}$ until use.

\section{CULTURE OF DERMAL FIBROBLASTS}

Cryopreserved dermal fibroblasts from primary cell bank in Centre for Tissue Engineering and Regenerative Medicine, UKMMC were used in this study. Cell culture was performed as previously described (Law et al. 2017a; Ruszymah et al. 2014). Cryopreserved fibroblasts were revived by culturing in F12/DMEM medium (Sigma, USA) containing 10\% FBS (Sigma), 1\% GlutaMAX (Gibco, USA), $1 \%$ ascorbic acid (Sigma) and 1\% antibioticantimycotic (Sigma). Medium change was performed every 2 to 3 days and the cells were trypsinized once it reached $80-90 \%$ confluence. For the experiment, fibroblasts were seeded at density $3,000 \mathrm{cells} / \mathrm{cm}^{2}$ in 6-well plate with F12/DMEM medium supplemented with $10 \%$ FBS (control group), 5\% hPL and 10\% hPL. A final concentration of $4 \mathrm{IU} / \mathrm{mL}$ heparin was added to the hPL supplemented medium to prevent spontaneous clotting of fibrinogen.

\section{CELL MORPHOLOGY, GROWTH PATTERN, AND CONFLUENCY}

The morphological changes, growth pattern, and confluency of dermal fibroblasts in culture were monitored and photographed using an inverted microscope at day 4,7 , and 10 .

\section{CELL VIABILITY AND PROLIFERATION}

Cell viability was determined using the trypan blue exclusion assay. The number of live and dead cells was counted using a hemocytometer. Proliferation rate was analyzed via the determination of population doubling time (PDT) using the following formula:

$$
P D T=\frac{t \log 2}{\log N_{2}-\log N_{1}}
$$

where $t$ denotes time in culture; $N_{2}$ denotes cell number at the end of the passage; and $N_{l}$ denotes cell number seeded at the beginning of the passage.

\section{TOTAL RNA EXTRACTION, CDNA SYNTHESIS, AND REAL-} TIME PCR

Total RNA of cultured fibroblasts was extracted using Direct-zol $^{\mathrm{TM}}$ RNA MiniPrep (Zymo Research, USA) according to manufacturer's instruction. Yield and purity of the extracted RNA were confirmed using a spectrophotometer. The extracted RNA was converted to cDNA using the iScript ${ }^{\mathrm{TM}}$ Reverse Transcription Supermix (Bio-Rad, USA). Real-time PCR was used to quantitatively analyze the gene expression of type I collagen ( $\mathrm{Col} \mathrm{I})$, type III collagen (Col III) and fibronectin (FN). The expression level of each targeted gene was normalized to glyceraldehyde 3-phosphate dehydrogenase (GAPDH). Primer sequences were adopted from previous study and showed in Table 1 (Xian et al. 2015). Real-time PCR reaction was performed using the $\mathrm{iTaq}^{\mathrm{TM}}$ Universal SYBR $^{\circledR}$ Green Supermix (Bio-Rad) in Rotor Gene Q RTPCR cycler (Qiagen, Germany) for 40 cycles. Melt curve analysis was done to check the reaction specificity. 
TABLE 1. RT-PCR primer sequences

\begin{tabular}{|c|c|c|c|}
\hline Gene & Accession number & Primer sequence (5'-3') & Product size (bp) \\
\hline GAPDH & NM 002046.5 & $\begin{array}{l}\text { F: caatgaccecttcattgacc } \\
\text { R: ttgattttggagggatctcg }\end{array}$ & 160 \\
\hline Col I & NM 000088.3 & $\begin{array}{l}\text { F: gtgctaaaggtgccaatggt } \\
\text { R: accaggttcaccgctgttac }\end{array}$ & 128 \\
\hline Col III & NM 000090.3 & $\begin{array}{l}\text { F: ccaggagctaacggtctcag } \\
\text { R: cagggtttccatctcttcca }\end{array}$ & 103 \\
\hline $\mathrm{FN}$ & NM 212482.2 & $\begin{array}{l}\text { F: aaaatggccagatgatgagc } \\
\text { R: tggcaccgagatattccttc }\end{array}$ & 141 \\
\hline
\end{tabular}

\section{WOUND HEALING ASSAY}

Silicon rubber strips were sterilized with $70 \%$ ethanol for $2 \mathrm{~h}$ before putting inside the 12-well plate. Subsequently, fibroblasts at density $3 \times 10^{5}$ cells $/ \mathrm{cm}^{2}$ were seeded. After overnight incubation, the silicon rubber strips attached inside the 12-well plate were removed, leaving a line of empty area known as the wound area. The wound closure was monitored via live imaging by capturing the image at 3 spots per well every $30 \mathrm{~min}$ for $72 \mathrm{~h}$ using a confocal microscope (Nikon, Japan). The images were analyzed using NIS Element software (Nikon) to measure the wound size. Wound closure was calculated using the formula:

$$
\text { Wound closure }(\%)=\frac{w(0)-w(t)}{w(0)} \times 100
$$

where $w(0)$ is wound area at time 0 and $w(t)$ is wound area at specific time.

\section{STATISTICAL ANALYSIS}

All data were presented as mean \pm standard error of mean and analyzed using the GraphPad Prism 7 (GraphPad
Software, USA). Statistical significance was calculated using one-way analysis of variance (ANOVA) followed by Tukey's multiple comparison test, where $p<0.05$ was considered significant.

\section{RESULTS}

\section{FIBROBLASTS CULTURED WITH HPL WERE MORE SPINDLE IN SHAPE AND MIGRATED IN SWIRLING MOTION}

Fibroblasts cultured with both FBS and hPL have a spindle-shaped. Nonetheless, fibroblasts cultured with hPL were slightly more spindle and elongated compared to those cultured with FBS. These differences can be observed throughout the culture period. In term of growth pattern, fibroblasts cultured with FBS did not demonstrate any specific pattern as the cells migrated and orientated randomly. The fibroblasts cultured with hPL migrated in swirling motion, leaving circle of empty spaces in the middle (Figure 1). Fibroblasts cultured with hPL have higher confluency compared to those cultured with FBS throughout the observation period whereby significant differences were detected between the $5 \%$ 
hPL and $10 \%$ hPL groups compared to the $10 \%$ FBS group at day 4, 7 and 10 (Figure 2). No significant differences were detected between the 5\% hPL and $10 \%$ hPL groups.
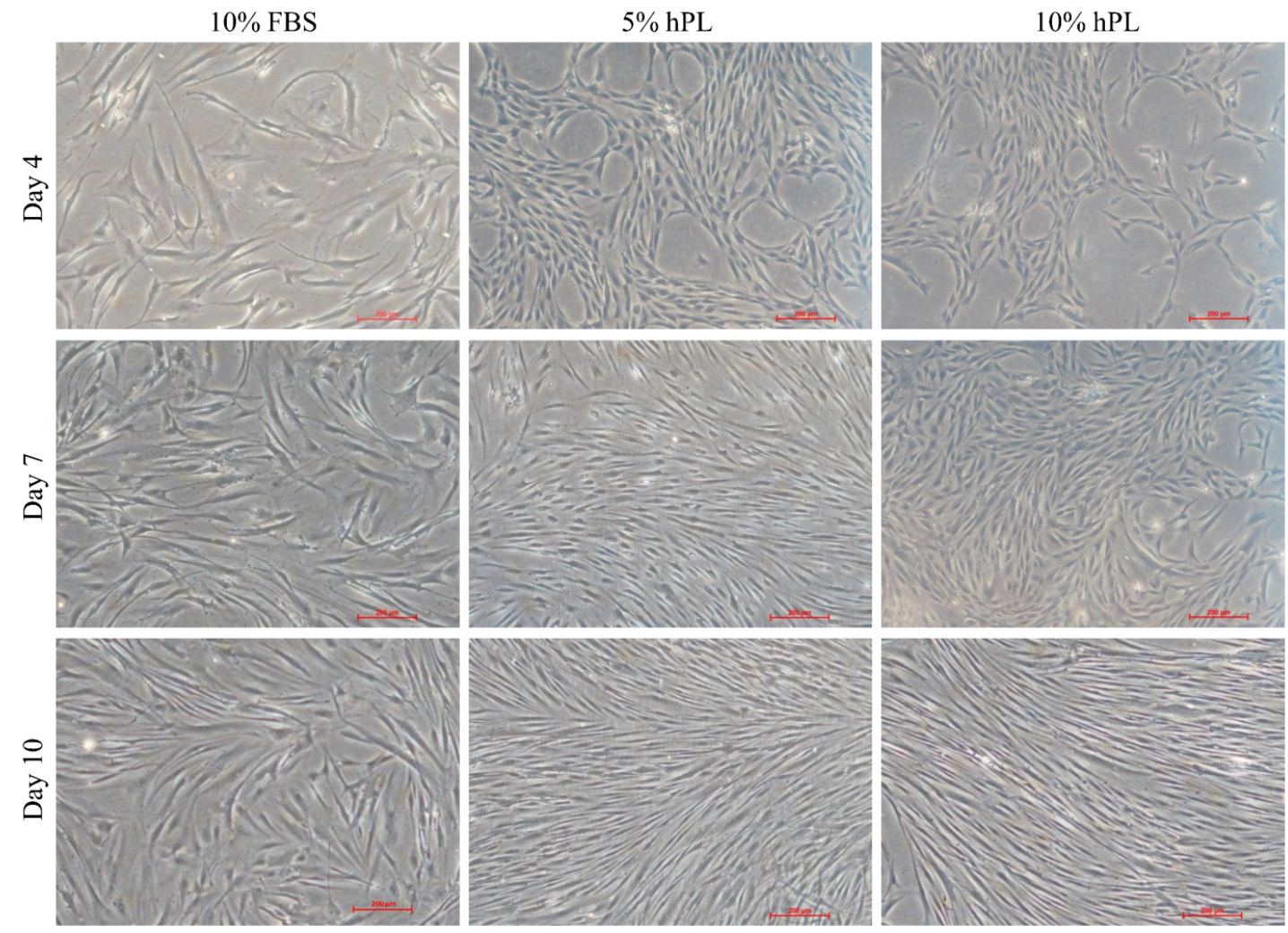

FIGURE 1. Morphology of cultured fibroblasts at day 4, 7, and 10. In all the groups, fibroblasts demonstrated typical spindle-shaped morphology. However, fibroblasts cultured with hPL were more spindle and smaller in size compared to those cultured with FBS

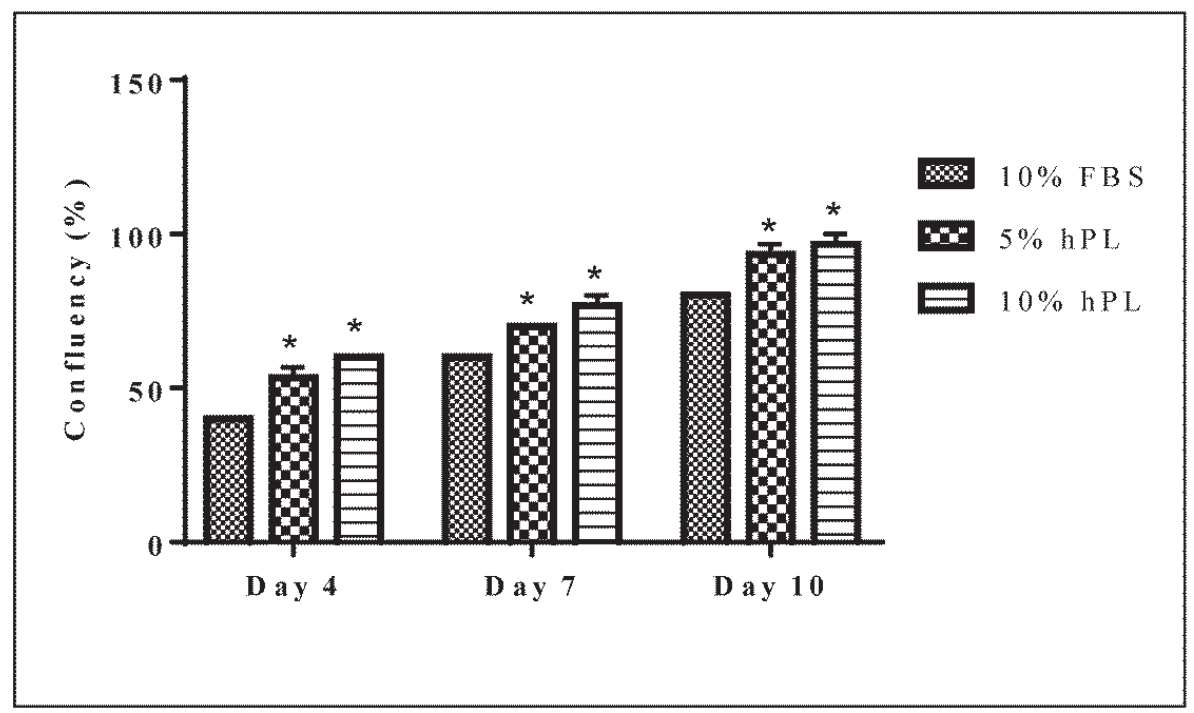

FIGURE 2. Fibroblast confluency at day 4, 7, and 10. Cell confluency increased with time in all the groups. The 5\% hPL and 10\% hPL demonstrated significant higher $(*$, $\mathrm{p}<0.05)$ confluency compared to the $10 \%$ FBS group at all measured time points $(n=6)$ 


\section{HPL INCREASED THE FIBROBLAST PROLIFERATION}

Confluency is not a good indicator for cell growth as it only indicates the surface area covered by cells. An accurate count of cell viability and number was performed using the hemocytometer with trypan blue to distinguish the live and dead cells. Fibroblasts cultured with FBS and hPL demonstrated excellent viability exceeding 90\% after 10 days in culture (Figure 3(a)). With starting seeding number of $3 \times 10^{4}$ cells $\left(3,000\right.$ cells $\left./ \mathrm{cm}^{2}\right)$ in 6 -well plate, we able to fetch $1.42 \times 10^{5} \pm 1.0 \times 10^{4}$ cells, $1.55 \times 10^{5} \pm 0.7 \times 10^{4}$ cells, and $2.35 \times 10^{5} \pm 2.4 \times 10^{4}$ cells, respectively, for the $10 \%$ FBS, $5 \%$ hPL and $10 \%$ hPL groups in 10 days (Figure 3(b)). Significant differences were detected between the $10 \%$ hPL group compared to the $10 \%$ FBS and 5\% hPL groups. Population doubling time was shortest for the $10 \%$ hPL group $(81.67 \pm 4.26 \mathrm{~h})$, followed by the $5 \% \mathrm{hPL}$ group $(101.70 \pm 2.96 \mathrm{~h})$ and 10\% FBS group $(108.00 \pm 5.20$ h) (Figure 3(c)). Again, significant differences were detected between the $10 \% \mathrm{hPL}$ group compared to the $10 \% \mathrm{FBS}$ and $5 \% \mathrm{hPL}$ groups.
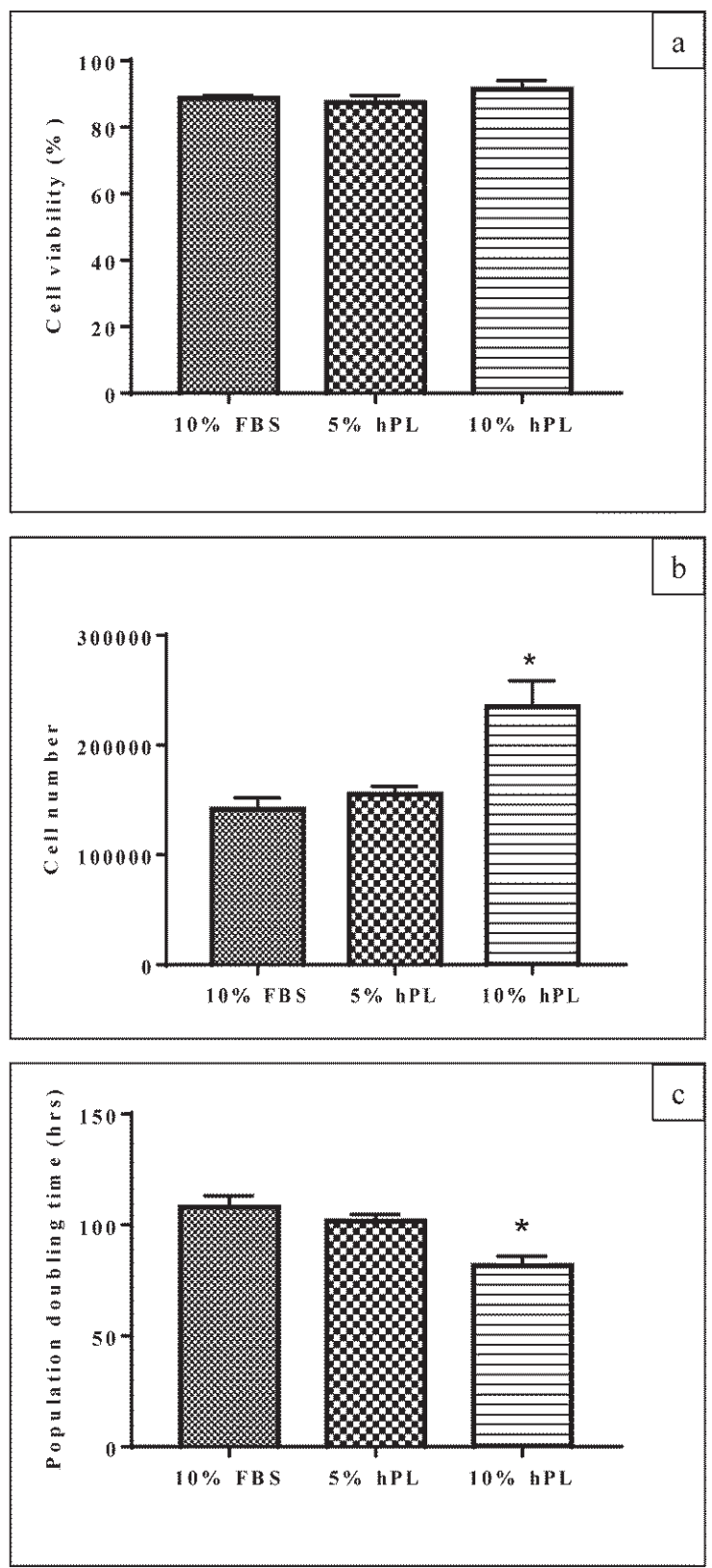

FIGURE 3. Measurement of fibroblast viability and proliferation at day 10 (a) All the groups demonstrated excellent viability exceeding $90 \%$, (b) The cell number at day 10 was significantly higher $(*, p<0.05)$ in the $10 \%$ hPL group compared to the $10 \%$ FBS and $5 \%$ hPL groups, and (c) The $10 \%$ hPL group has significantly shorter $(*, p<0.05)$ population doubling time compared to the $10 \%$ FBS and $5 \%$ hPL groups $(n=6)$ 


\section{HPL DECREASED THE FIBROBLAST ECM GENE} EXPRESSION

One of the most important functions of fibroblast is the secretion of ECM proteins. Thus, RT-PCR was performed to check the ECM gene expression of the fibroblasts cultured with hPL. We found that cells cultured with hPL have significantly lower expression of all the measured ECM genes compared to those cultured with FBS (Figure 4). Even though it is not significantly different, we also noticed that the expression of the ECM genes was lower for the $10 \% \mathrm{hPL}$ group compared to the $5 \% \mathrm{hPL}$ group. The expression of Col I was 4.15-fold and 7.27-fold lower in the $5 \% \mathrm{hPL}$ and $10 \%$ hPL groups, respectively, compared to the $10 \%$ FBS group. The expression of Col III was 3.64-fold and 5.76-fold lower in the 5\% hPL and $10 \%$ hPL groups, respectively, compared to the $10 \%$ FBS group. For FN, its expression was 1.70-fold and 2.20-fold lower in the 5\% hPL and $10 \%$ hPL groups, respectively, compared to the $10 \%$ FBS group.

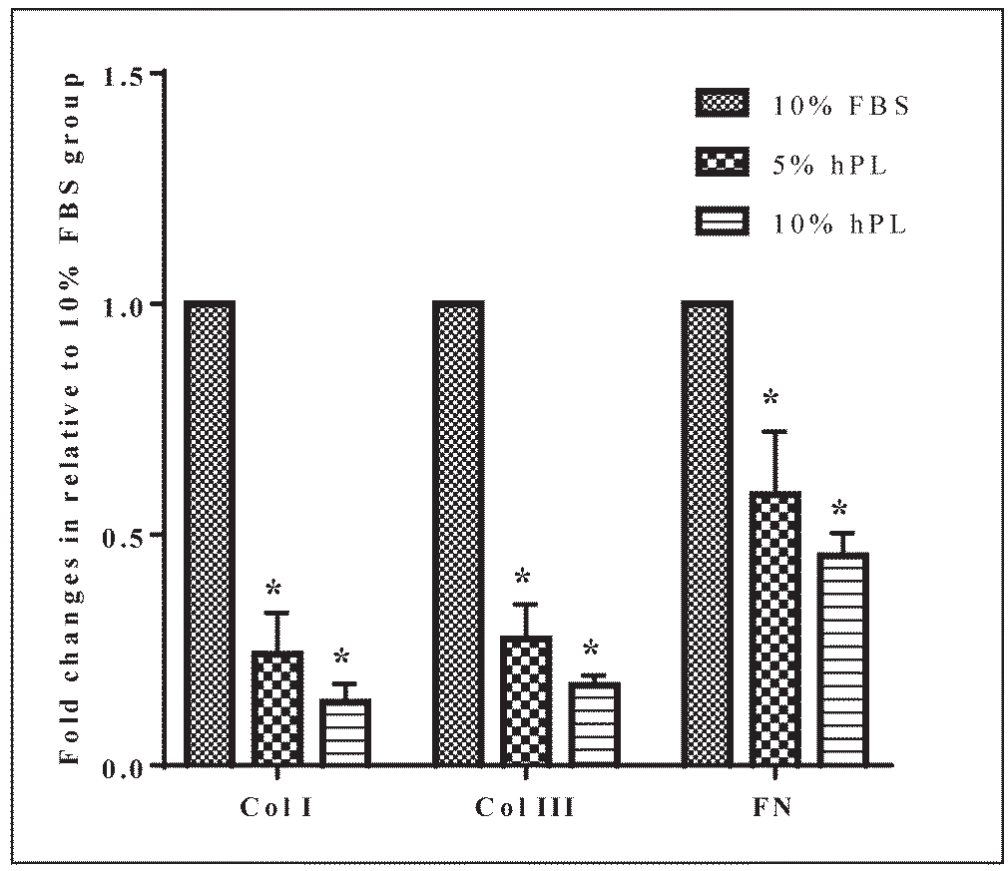

FIGURE 4. Fibroblast ECM gene expression. The expression of ECM genes was significantly lower $(*, p<0.05)$ in cells cultured with hPL compared to those cultured with FBS $(n=3)$

\section{HPL SLOWDOWN FIBROBLAST WOUND HEALING}

Fibroblast migration decreased drastically when the cells were cultured with hPL whereby significant differences were detected between the hPL groups and 10\% FBS group.
Complete wound closure was observed in the $10 \%$ FBS group after $72 \mathrm{~h}$. The wound closure was approximately $30 \%$ in the $5 \%$ hPL group and less than $10 \%$ in the $10 \%$ hPL group after $72 \mathrm{~h}$ (Figure 5). 

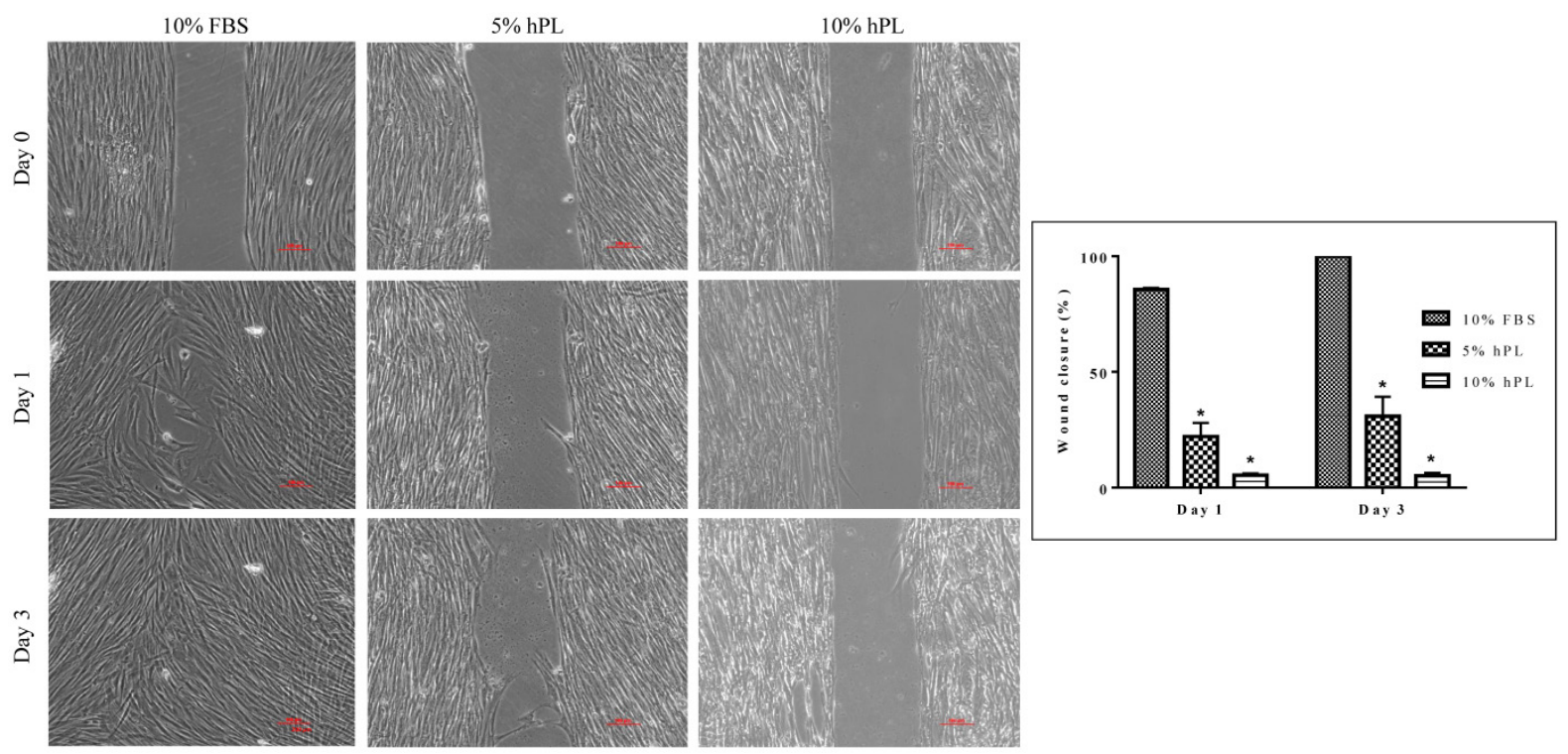

FIGURE 5. Fibroblast wound closure. The migration rate decreased for the fibroblasts cultured with hPL. Significant differences $(*, p<0.05)$ were detected between the hPL groups and $10 \%$ FBS group $(\mathrm{n}=3)$

\section{DISCUSSION}

Serum is often needed in the culture medium to support survival and growth of most types of cells. Nowadays, FBS is the most commonly used serum supplement for cell culture as it is easily available and highly efficient in promoting cell growth. Routine use of FBS for cell culture in research settings is not a big issue despite ethical concern with the animal welfare during the serum production (Tekkatte et al. 2011). However, the use of cells expanded with FBS in clinical settings is worrisome as the residue of animal proteins on cultured cells may illicit unwanted reactions such as allergic response and rejection. Furthermore, FBS may carry animal pathogens that may cause serious illnesses and harms to human.

In the hospital blood bank, various types of blood products are being stored for emergency usage. One of the blood products is platelet concentrate that only can be kept for 5 days (National Blood Centre 2016). Platelet concentrates are discarded upon exceeding its shelf life.
In this study, we examined the possibility of converting the expired platelet concentrates into hPL for cell culture purposes. The use of expired platelet concentrates to prepare hPL offered many advantages including the raw materials (platelet concentrates) are free, no competition with blood bank for donors and no ethical issues. As the platelet concentrates are collected from low risk population and are screened for transfusion-transmissible infections, clinical use of cells cultured with hPL are safer compared to using the cells expanded with FBS.

Therapeutic use of dermal fibroblasts has been on the raise in line with the increased popularity in using stem cell to promote wound healing. Multiple studies have been conducted to determine the possibility of using fibroblasts with and without a supportive matrix to enhance skin tissue regeneration (Law et al. 2017c, 2016). Many of the clinical studies conducted used FBS to expand the fibroblasts. However, an alternative to FBS is highly desirable to circumvent the disadvantages of FBS as mentioned earlier. 
We collected expired platelet concentrates from hospital blood bank and processed it into hPL to determine the possibility of substituting FBS with hPL to culture human dermal fibroblasts. Two concentrations, 5 and $10 \%(\mathrm{v} / \mathrm{v})$, of hPL are tested in current study. We selected $5 \% \mathrm{hPL}$, a relatively low concentration in cell culture, as hPL is rich in growth factors and 5\% might be sufficient to promote cell growth. In a preliminary study, we found that $2 \mathrm{IU} / \mathrm{mL}$ heparin was not sufficient to prevent spontaneous clotting of hPL in culture (data not shown). Thus, a higher concentration of $4 \mathrm{IU} / \mathrm{mL}$ was used in this study. No clotting was found in the medium added with 4 $\mathrm{IU} / \mathrm{mL}$ of heparin.

We noticed that there were slight differences in the morphology of fibroblasts cultured with FBS and hPL. Even though all the fibroblasts were spindle in shape, cells cultured with hPL were smaller and slender compared to those cultured with hPL. Similar observation has been described by Phetfong et al. (2017) that compared the use of FBS and hPL as serum supplement to culture adiposederived MSCs. We also observed that fibroblasts cultured with hPL migrated in swirling motion that leaves circular cell-free area. This pattern of cell migration has been found to be similar to the description of Jonsdottir-Bush et al. (2013) that used hPL to culture bone marrow-derived MSCs.

HPL was found to be superior compared to FBS in promoting fibroblast proliferation whereby the total cell number was significantly higher and population doubling time was significantly shorter in the $10 \% \mathrm{hPL}$ group compared to the $10 \%$ FBS group. Supplementation with $5 \% \mathrm{hPL}$ was found to give comparable effects as $10 \%$ FBS in supporting fibroblast proliferation. These discrepancies were likely to be attributed by the differences in the concentration of important growth factors within the serum supplements. HPL has been reported to be rich in growth factor such as platelet-derived growth factor (PDGF), transforming growth factor (TGF), epidermal growth factor (EGF), insulin-like growth factor (IGF) and basic fibroblast growth factor (bFGF) that were known to promote cell proliferation (Antoninus et al. 2015; Lohmann et al. 2012).

Surprisingly, our results showed that fibroblasts cultured with hPL have significantly lower expression of ECM genes, i.e. Col I, Col III and FN. The lower ECM gene expression is not ideal for fibroblasts that will be used clinically to promote wound healing as ECM accumulation is very important during wound healing to support skin tissue regeneration. Furthermore, we also found that fibroblast wound closure slowed down significantly in presence of hPL. Contradict results have been reported by Sergeeva et al. (2016) that showed that hPL promoted the wound closure of monolayer fibroblasts. Heparin is an anti-coagulant added to hPL to prevent clot formation. In the previous study, heparin has been found to inhibit Col I secretion of dermal fibroblasts in confluent culture (Ferrao \& Mason 1993). Heparin also has been reported to suppress the gene expression of $\mathrm{Col} \mathrm{I}$ and $\mathrm{Col}$ III of fibroblasts isolated from transverse carpal ligament of patients with carpal tunnel syndrome (Jeong et al. 2006). Thus, the suppression of ECM gene expression seen in this study might be due to the $4 \mathrm{IU} / \mathrm{mL}$ heparin presence in the hPL-supplemented medium. Similarly, the inhibition of dermal fibroblast migration might also cause by heparin as heparin has been reported to suppress the chemotaxis of lung fibroblasts induced by PDGF and to inhibit the migration of vascular smooth muscle cells (Au et al. 1993; Sasaki et al. 2000).

The changes in characteristic and functionality of cells in culture are reversible by altering the culture environment (Fernandez-Rebollo et al. 2017). In addition, the functionality of transplanted cells will change according to the in vivo environment. Thus, future study is needed to compare the highly proliferative fibroblasts cultured with hPL and the slower growing fibroblasts cultured with FBS in term of their ability to promote in vivo wound healing. Preconditioning of the fibroblasts expanded with hPL might be needed before transplantation if the cell functionality changes affect the wound healing.

\section{CONCLUSION}

HPL prepared from expired platelet concentrates has the potential to substitute FBS for xenogeneic-free expansion of fibroblasts as it enhances the cell proliferation. Nonetheless, extra experiments are needed to ensure that the changes in ECM gene expression and cell migration will not affect the efficacy of the fibroblasts in promoting in vivo wound healing.

\section{ACKNOWLEDGEMENTS}

This works was supported by research grants from Universiti Kebangsaan Malaysia Medical Centre (FF2019-553 and FF-2019-450/1). The authors declare that there are no conflicts of interest. 


\section{REFERENCES}

Abdelrazik, H., Spaggiari, G.M., Chiossone, L. \& Moretta, L. 2011. Mesenchymal stem cells expanded in human platelet lysate display a decreased inhibitory capacity on T- and NK-cell proliferation and function. European Journal of Immunology 41(11): 3281-3290.

Antoninus, A.A., Widowati, W., Wijaya, L., Agustina, D., Puradisastra, S., Sumitro, S.B., Widodo, M.A. \& Bachtiar, I. 2015. Human platelet lysate enhances the proliferation of Wharton's jelly-derived mesenchymal stem cells. Biomarkers and Genomic Medicine 7(3): 87-97.

Astori, G., Amati, E., Bambi, F., Bernardi, M., Chieregato, K., Schäfer, R., Sella, S. \& Rodeghiero, F. 2016. Platelet lysate as a substitute for animal serum for the ex-vivo expansion of mesenchymal stem/stromal cells: Present and future. Stem Cell Research \& Therapy 7(1): 93-99.

Au, Y.P., Kenagy, R.D., Clowes, M.M. \& Clowes, A.W. 1993. Mechanisms of inhibition by heparin of vascular smooth muscle cell proliferation and migration. Haemostasis 23(Supp 1): 177-182.

Budi Harto, P.H.b., Mahmud, M.H.b., Othman, A.H.b., Ngadenin, N.H., Mohd Azahar, N.S.b., Hassan, M.N.F.b., Mohd Yahaya, N.H., Abdul Rani, R., Leong, C.F., Ng, M.H. \& Law, J.X. 2019. Human platelet lysate promotes proliferation but fails to maintain chondrogenic markers of chondrocytes. Sains Malaysiana 48(10): 2169-2176.

Fazzina, R., Iudicone, P., Mariotti, A., Fioravanti, D., Procoli, A., Cicchetti, E., Scambia, G., Bonanno, G. \& Pierelli, L. 2016. Culture of human cell lines by a pathogen-inactivated human platelet lysate. Cytotechnology 68(4): 1185-1195.

Fernandez-Rebollo, E., Mentrup, B., Ebert, R., Franzen, J., Abagnale, G., Sieben, T., Ostrowska, A., Hoffmann, P., Roux, P.F., Rath, B., Goodhardt, M., Lemaitre, J.M., Bishof, O., Jakob, F. \& Wagner, W. 2017. Human platelet lysate versus fetal calf serum: These supplements do not select for different mesenchymal stromal cells. Scientific Reports 7: 5132 .

Ferrao, A.V. \& Mason, R.M. 1993. The effect of heparin on cell proliferation and type-I collagen synthesis by adult human dermal fibroblasts. Biochima et Biophysica Acta (BBA) Molecular Basic of Disease 1180(3): 225-230.

Griffiths, S., Baraniak, P.R., Copland, I.B., Nerem, R.M. \& McDevitt, T.C. 2013. Human platelet lysate stimulates highpassage and senescent human multipotent mesenchymal stromal cell growth and rejuvenation in vitro. Cytotherapy 15(12): 1469-1483.

Gstraunthaler, G., Rauch, C., Feifel, E. \& Lindl, T. 2015. Preparation of platelet lysates for mesenchymal stem cell culture media. Journal of Stem Cells Research, Reviews \& Reports 2(1): 1021 .

Hemeda, H., Giebel, B. \& Wagner, W. 2014. Evaluation of human platelet lysate versus fetal bovine serum for culture of mesenchymal stromal cells. Cytotherapy 16(2): 170-180.
Jeong, S.H., Na, M.H., Lee, J.S., Song, S.H., Yoon, E.S., Dhong, E.S. \& Kim, H.J. 2006. The effect of heparin on gene expression of collagen, MMP, TGF-beta isoforms using cultured fibroblasts from transverse carpal ligament of carpal tunnel syndrome. Archieves of Plastic Surgergy 33(4): 427-432.

Jochems, C.E.A., van der Valk, J.B.F., Stafleu, F.R. \& Baumans, V. 2002. The use of fetal bovine serum: Ethical or scientific problem? Alternatives to Laboratory Animals 30(2): 219-227.

Jonsdottir-Buch, S.M., Lieder, R. \& Sigurjonsson, O.E. 2013. Platelet lysates produced from expired platelet concentrates support growth and osteogenic differentiation of mesenchymal stem cells. PLoS ONE 8(7): e68984.

Juhl, M., Tratwal, J., Follin, B., Søndergaard, R.H., Kirchhoff, M., Ekblond, A., Kastrup, J. \& Haack-Sørensen, M. 2016. Comparison of clinical grade human platelet lysates for cultivation of mesenchymal stromal cells from bone marrow and adipose tissue. Scandinavian Journal of Clinical and Laboratory Investigation 76(2): 93-104.

Law, J.X., Chowdhury, S.R., Aminuddin, B.S. \& Ruszymah, b.H.I. 2017a. Role of plasma-derived fibrin on keratinocyte and fibroblast wound healing. Cell Tissue Bank 18(4): 585-595

Law, J.X., Chowdhury, S.R., Saim, A.B. \& Idrus, R.B.H. 2017 b. Platelet-rich plasma with keratinocytes and fibroblasts enhance healing of full-thickness wounds. Journal of Tissue Viability 26(3): 208-215.

Law, J.X., Liau, L.L., Saim, A., Yang, Y. \& Idrus, R. 2017c. Electrospun collagen nanofibers and their applications in skin tissue engineering. Tissue Engineering and Regenerative Medicine 14(6): 699-718.

Law, J.X., Musa, F., Ruszymah, B.H.I., El Haj, A.J. \& Yang, Y. 2016. A comparative study of skin cell activities in collagen and fibrin constructs. Medical Engineering \& Physics 38(9): 854-861.

Law J.X., Chowdhury, S.R., Aminuddin, B.S. \& Ruszymah, B.H.I. 2015. Concentration-dependent effect of plateletrich plasma on keratinocyte and fibroblast wound healing. Cytotherapy 17: 293-300.

Lohmann, M., Walenda, G., Hemeda, H., Joussen, S., Drescher, W., Jockenhoevel, S., Hutschenreuter, G., Zenke, M. \& Wagner, W. 2012. Donor age of human platelet lysate affects proliferation and differentiation of mesenchymal stem cells. PLOS ONE 7(5): e37839.

National Blood Centre. 2016. Transfusion Practice Guidelines for Clinical and Laboratory Personnel. Malaysia: Ministry of Health Malaysia.

Phetfong, J., Tawonsawatruk, T., Seenprachawong, K., Srisarin, A., Isarankura-Na-Ayudhya, C. \& Supokawej, A. 2017. Re-using blood products as an alternative supplement in the optimisation of clinical-grade adipose-derived mesenchymal stem cell culture. Bone Joint Research 6(7): 414-422. 
Ruiz-Moneo, P., Molano-Muñoz, J., Prieto, E. \& Algorta, J. 2013. Plasma rich in growth factors in arthroscopic rotator cuff repair: A randomized, double-blind, controlled clinical trial. Arthroscopy 29(1): 2-9.

Russell, K.A., Gibson, T.W., Chong, A., Co, C. \& Koch, T.G. 2015. Canine platelet lysate is inferior to fetal bovine serum for the Iisolation and propagation of canine adipose tissueand bone marrow-derived mesenchymal stromal cells. PLoS ONE 10(9): e0136621.

Ruszymah Bt Hj Idrus, Mohd Adha bin P Rameli, Kiat Cheong Low, Jia Xian Law, Kien Hui Chua, Mazlyzam Bin Abdul Latiff \& Aminuddin Bin Saim. 2014. Full-thickness skin wound healing using autologous keratinocytes and dermal fibroblasts with fibrin: Bilayered versus singlelayered substitute. Advances in Skin \& Wound Care 27(4): 171-180.

Sasaki, M., Kashima, M., Ito, T., Watanabe, A., Sano, M., Kagaya, M., Shioya, T. \& Miura, M. 2000. Effect of heparin and related glycoaminoglucan on PDGF-induced lung fibroblast proliferation, chemotactic response and matrix metalloproteinases activity. Mediators of Inflammation 9(2): 85-91.

Schallmoser, K. \& Strunk, D. 2009. Preparation of pooled human platelet lysate (pHPL) as an efficient supplement for animal serum-free human stem cell cultures. Journal of Visualized Experiment 32: 1523.

Sergeeva, N.S., Shanskii, Y.D., Sviridova, I.K., Karalkin, P.A., Kirsanova, V.A., Akhmedova, S.A. \& Kaprin, A.D. 2016. Analysis of reparative activity of platelet lysate: Effect on cell monolayer recovery in vitro and skin wound healing in vivo. Bulletin of Experimental Biology and Medicine 162(1): 138-145.
Tekkatte, C., Gunasingh, G.P., Cherian, K.M. \& Sankaranarayanan, K. 2011. "Humanized" stem cell culture techniques: The animal serum controversy. Stem Cells International 2011: 504723 .

Wirohadidjojo, Y.W., Budiyanto, A. \& Soebono, H. 2016. Platelet-rich fibrin lysate can ameliorate dysfunction of chronically UVA-Irradiated human dermal fibroblasts. Yonsei Medical Journal 57(5): 1282-1285.

Yao, T. \& Asayama, Y. 2017. Animal-cell culture media: History, characteristics, and current issues. Reproductive Medicine and Biology 16(2): 99-117.

Muhammad Najib Fathi Bin Hassan, Zheng Yie Yap, Min Hwei Ng \& Jia Xian Law*

Centre for Tissue Engineering and Regenerative Medicine Faculty of Medicine

Universiti Kebangsaan Malaysia Medical Centre

56000 Cheras, Kuala Lumpur, Federal Territory Malaysia

Yee Loong Tang

Department of Pathology

Faculty of Medicine

Universiti Kebangsaan Malaysia Medical Centre 56000 Cheras, Kuala Lumpur, Federal Territory Malaysia

*Corresponding author; email: lawjx@ppukm.ukm.edu.my

Received: 14 May 2020

Accepted: 4 December 2020 